\title{
AVALIAÇÃO DA SILAGEM DE CAPIM-ELEFANTE CV. NAPIER (Pennisetum purpureum) COM DIFERENTES TIPOS DE ADITIVOS
}

\author{
LUCATTO JUNIOR, Aldoir José ${ }^{104}$ \\ MELLO, Sílvio de Paula ${ }^{105}$
}

Recebido em: 2008-07-16

Aprovado em: 2008-08-28

ISSUE DOI: $10.3738 / 1982.1158 .115$

RESUMO: O presente trabalho foi realizado na área experimental da Faculdade Dr. Francisco Maeda no município de Ituverava-SP, com o objetivo de avaliar as percentagens de matéria seca, proteína bruta e de nitrogênio na silagem de capim-elefante (Pennisetum purpureum Schum) cv. Napier com diferentes aditivos. $\mathrm{O}$ delineamento utilizado foi inteiramente casualizado, com seis tratamentos: T1: silagem $+0,5 \%$ de uréia; T2: silagem + 10\% de Milho Desintegrado com Palha e Sabugo; T3: silagem + 10\% de farelo de soja; T4: silagem + 10\% de farelo de milho; T5: silagem + 10\% de farelo de trigo; T6: testemunha, com três repetições. A partir dos resultados obtidos, verificou-se que as percentagens de matéria seca (\%MS) não apresentaram diferença significativa entre os tratamentos. Já para percentagem de proteína bruta (\%PB) e de nitrogênio, o tratamento que utilizou $10 \%$ de farelo de soja na silagem de capim elefante, apresentou melhor resposta com valores de $15,47 \%$ e $2,47 \%$, respectivamente.

Palavras-chaves: Forrageira. Napier. Ensilagem. Qualidade.

SUMMARY: The current work was made in an experimental Campus of Dr. Francisco Maeda University at Ituverava-SP Brazil, with the proposal of avaliaty the percentages of dry material, raw protein and nitrogen in silage of elephant-grass (Pennisetum purpureum Schum) cv. Napier with different kiuds of additives. The delineate used was totally casual, with six treatments (T): T1: silage $+0.5 \%$ of urea; T2: silage $+10 \%$ of MDPS; T3: silage $+10 \%$ of soy bran; T4: silage $+10 \%$ of corn bran; T5: silage $+10 \%$ of wheat bran; T6: standard, with three repetition. Considering the obtained results, was verified that the percentages of dry material (\%MS) didn't show significant differences between the treatments. But for the percentage of raw protein (\%PB) and nitrogen, the treatment that used $10 \%$ of soy bran in the silage of elephant-grass, showed results of $15,47 \%$ and $2,47 \%$, respectively.

Keywords: Forage. Napier. Silage. Quality.

${ }^{104}$ Engenheiro Agrônomo
${ }^{105}$ Zootecnista. Prof. Dr. Faculdade Dr. Francisco Maeda. Fundação Educacional de Ituverava. 


\section{INTRODUÇÃO}

O capim-elefante é reconhecidamente uma das gramíneas tropicais de maior potencial produtivo , desta forma, uma das plantas forrageiras utilizadas para conservação na forma de silagem (VILELA, 1990).

A estacionalidade de produção das plantas forrageiras demanda o uso de práticas de conservação de forragens durante o período de crescimento característico dessas plantas, a fim de serem utilizadas ao longo do período de escassez, minimizando os efeitos da disponibilidade estacional de alimentos. A silagem tem sido usada como instrumento auxiliar na manutenção e amplificação da produção animal, principalmente durante o período de menor produção das forragens.

Evidências experimentais têm sugerido que a inclusão de uma fonte de carboidratos solúveis ao capim elefante durante a ensilagem, pode melhorar consideravelmente a qualidade final das silagens. Assim, o baixo teor de carboidratos solúveis presentes no capim elefante não é suficiente para haver uma adequada fermentação do material ensilado e, também, o teor protéico não é satisfatório para atender às necessidades dos ruminantes, fazendo com que seja necessário à utilização de métodos especiais de ensilagem com a finalidade de alterar a composição em ácidos orgânicos e conseqüentemente conseguir-se um produto de boa qualidade (ONSELEN; LOPES, 1988).

Essas substâncias adicionadas à silagem são denominadas aditivos e devem ser utilizados no processo de ensilagem com o intuito de reduzir os riscos, diminuindo as perdas de matéria seca, melhorando a qualidade higiênica, limitando as fermentações secundárias, melhorando a estabilidade aeróbia e aumentando o valor nutritivo da silagem produzida (HENDERSON, 1993).

O capim elefante, ao ser cortado em idade inferior a 90 dias de crescimento, quando a produção e o valor nutritivo são adequados, o excesso de umidade presente (80\% ou mais) aumenta o risco de fermentação indesejável, com maior produção de ácidos acético e butírico, de nitrogênio amoniacal, amidas e aminas (McDONALD et al. 1991).

Dentro da classificação dos aditivos segundo Corrêa; Pott (2001), o farelo de trigo e o fubá de milho são classificados como substratos ou fontes de nutrientes, podendo também agir como estimulantes de fermentação, absorventes ou fontes de nutrientes.

A adição de milho desintegrado com palha e sabugo (MDPS) à forragem de capimelefante deve melhorar a qualidade das silagens, segundo Wieringa (1958), por meio do 
aumento da porcentagem de matéria seca, que restringe o desenvolvimento de fermentações secundárias pelo aumento da pressão osmótica. A adição de MDPS à primeira vista não favoreceria a fermentação pelo aumento do teor de carboidratos solúveis da forragem, uma vez que quase a totalidade dos extrativos não nitrogenados desse aditivo está na forma de amido, o qual, segundo Toth et al. (1956), não é utilizado como substrato pelas bactérias.

Muitos estudos realizados com o objetivo de avaliar a qualidade de silagens adicionadas desses aditivos têm mostrado bons resultados. Portanto, o objetivo deste trabalho é avaliar os teores de proteína bruta, nitrogênio e de matéria seca em silagem de capim elefante cv. napier com diferentes tipos de aditivos.

\section{REVISÃO DE LITERATURA}

Segundo Andrade (1999), a estacionalidade de produção das plantas forrageiras, provocada por baixas temperaturas, umidade e luminosidade insuficientes em parte do ano, é um fator responsável pela baixa taxa de desfrute e acentuada queda na produção de leite e carne, exigindo o planejamento e a execução de práticas que visem a conservação de forragens para esses períodos críticos, tais como: vedação de pastagens, manejo de capineiras (capim-elefante, cana-de-açúcar), aproveitamento de restos de culturas ou palhadas, plantio de culturas de inverno, fenação e ensilagem (DEMARCHI; BOIN; BRAUN, 1995).

Segundo Pupo (1979), o capim elefante (Pennisetum purpureum) erroneamente chamado de capim napier (nome de uma de suas variedades), é uma gramínea perene, cespitosa, natural da África, que foi introduzida no Brasil por volta de 1920, apresentando excelente adaptação. É rústica, possui rizomas curtos e grossos e, crescendo livremente, atinge três metros ou até mais de altura. É perene, multiplicada através de rizomas ou de porções de colmo que, quando plantados, dão origem a novas plantas. A reprodução por sementes é pequena, pois há uma defasagem na emergência de estigmas e estames, dificultando a fecundação. $\mathrm{O}$ crescimento inicial é rápido e a planta forma uma touceira volumosa (KISSMANN, 1997). Apresenta relativa resistência à seca, frio e fogo, porém fica crestado com geadas, rebrotando com vigor na primavera. É exigente em fertilidade e vegeta bem desde solos enxutos até um pouco mais úmidos.

As variedades mais utilizadas e recomendadas são as que apresentam florescimento tardio, sem joçal, com colmos macios e tenros, sendo, portanto, mais empregadas a Napier, Mineiro, Cameroon, Porto Rico, Vrukwona, Taiwan A-148, Taiwan A-144 e Elefante Roxo. 
Essas variedades são bastante semelhantes, sendo que a diferenciação é feita por diâmetro, dureza e porte do colmo, comprimento, número de folhas e época de florescimento. A composição química difere-se pouco entre as variedades, sendo que a variação maior ocorre com a idade da planta (EVANGELISTA; ROCHA, 1997).

O capim elefante deve ser plantado durante a estação chuvosa, a partir das primeiras e boas chuvas da primavera, até o mês de fevereiro, quando ainda há grande concentração de chuvas. Como produz sementes em taxa reduzidíssima (praticamente nula), sua multiplicação se dá exclusivamente por meio de mudas (colmos), que após a retirada dos "palmitos" (pontas) são deitadas em sulcos abertos no terreno. As melhores mudas são aquelas que possuem mais de 100 dias de idade (maduras), pois, brotam em quantidade bem superior, garantindo um bom stand da cultura. Essas mudas suportam viagens de 5 a 20 dias, desde que mantidas constantemente à sombra. A quantidade de mudas necessárias, bem como a distância entre os sulcos de plantio, dependerão das disponibilidades de mudas, mão-de-obra e recursos financeiros do proprietário. Normalmente, planta-se em sulcos de $15 \mathrm{~cm}$ de profundidade, espaçados $50 \mathrm{~cm}$ uns dos outros, gastando-se, em média, 2-4 toneladas de mudas para formar um hectare. Resultados muito bons também são conseguidos quando a distância entre sulcos é de 0,70 e até 1,0 metro (PUPO, 1979).

Segundo o NRC (1996), o capim Napier aos 30 dias de crescimento apresenta 20,0\% de MS, 70,0\% de FDN, 14,3\% de Lignina, 55,0\% de NDT, 8,7\% de PB, 2,2\% de proteína indisponível em detergente ácido (PIDA, como \% da PB), 8,0\% de amido (\% dos carboidratos não estruturais), 3,0\% de EE e 9,0\% de MM. Já o mesmo capim aos 60 dias de crescimento, apresenta 23,0\% de MS, 75,0\% de FDN, 18,7\% de Lignina, 53,0\% de NDT, 7,8\% de PB, $2,2 \%$ de PIFDA (\% da PB), 8,0\% de amido (\% dos CNE), 1,0\% de EE e 6,0\% de MM.

Das forrageiras tropicais, o capim-elefante (Pennisetum purpureum) vem sendo utilizado com grande freqüência para produção de silagem, devido à sua alta produtividade (FERREIRA; SILVA; GOMIDE, 1974) e valor nutritivo (ROCHA et al. 2001), quando comparado com as demais espécies. Além disso, trata-se de uma planta perene, evitando-se gastos anuais de implantação da cultura (REZENDE et al. 2002; SOUZA et al. 2001).

Adubação, frequiência de pastejo e resíduo pós pastejo, são alguns dos fatores de manejo que, quando conduzidos de forma inadequada, são decisivos para determinar o valor nutritivo da forrageira tropical e podem, em parte, explicar o conceito generalizado de que a planta tropical é de baixa qualidade (CORSI; MARTHA JÚNIOR, 1997). No entanto, em condições de manejo adequado, diversos autores têm reportado resultados da ordem de 13 a 
$20 \%$ de PB e 53 a $65 \%$ de FDN para plantas forrageiras tropicais (REEVES et al. 1996; COWAN; LOWE, 1998, SANTOS; JUCHEM, 2000).

Pedreira e Matos (1982) trabalharam com oito cultivares de capim-elefante e relataram produções médias anuais entre 10,9 e 14,1 toneladas de matéria seca por hectare e teor protéico entre 9,6 e $11,6 \%$.

O corte deverá ser feito quando o capim apresentar 1,20 - 1,50 metros de altura, a 30 $40 \mathrm{~cm}$ do solo, com segadeira, fazendo-se a picagem na boca do silo. Ressalta-se que não é preciso possuir, necessariamente, uma área destinada exclusivamente ao corte e ensilagem do capim elefante. Basta vedar uma parcela dos pastos desse capim e utilizá-la para o citado fim (PUPO, 1979).

Segundo Pupo (1979), a silagem é um alimento volumoso obtido de forragens suculentas, nutritivas e palatáveis, produzidas na estação "das águas", conservando-as através de fermentações até o período de escassez, onde será fornecida aos animais para suprir as deficiências de alimentação. Foi descrita pela primeira vez pelo escocês James Johnston, em 1843, e foi introduzida no Brasil provavelmente no final desse mesmo século. Muitas pessoas a chamam, erradamente, de ensilagem, termo este que deve ser empregado para o processamento da forrageira que irá se tornar silagem. Ao contrário do que muitos pensam, a ensilagem não melhora a qualidade da forrageira, podendo, sim, piorá-la, pois é comum a ocorrência de perdas no seu valor nutritivo e até na palatabilidade.

O objetivo básico da ensilagem é preservar a forragem com o mínimo de perdas de nutrientes para que o animal possa receber alimentação com a composição próxima à da original. A essência do processo é promover rápida fermentação lática oriunda de bactérias predominantemente homofermentativas sob condições anaeróbicas, as quais ocorrem naturalmente (MERRY et al. 1993). Infelizmente, as bactérias láticas não são os únicos microrganismos que ocorrem nas silagens. Inúmeros microrganismos indesejáveis, como enterobactérias e clostrídios, podem competir com as bactérias láticas pelos mesmos substratos, dependendo das condições encontradas no silo. Além disso, as bactérias láticas são divididas em dois grandes grupos, que diferem quanto à produção de lactato a partir de açúcares. As homofermentativas produzem ácido lático a partir de glucose e frutose, sem perda de MS, enquanto as homofermentativas produzem ácido lático e também outros produtos tais como $\mathrm{CO}_{2}$, etanol e ácido acético, que levam a perdas de matéria seca e são menos eficientes no abaixamento do pH (McDONALD et al. 1991).

No Brasil, os estudos para ensilagem de gramíneas tropicais, mais recentemente assumiram basicamente três direções: a aplicação de aditivos no momento da ensilagem, a 
utilização de outras variedades além do capim elefante, tais como Tanzânia e Mombaça, e a associação de áreas exploradas para pastejo rotacionado e produção de silagem (MORAIS, 1999).

Um método para minimizar as perdas pela ensilagem, segundo Lavezzo (1994), o emurchecimento aumenta o teor de matéria seca, porém esse valor nem sempre atinge níveis adequados. Além disso, o valor nutritivo da silagem também poderá ser reduzido, devido a maior decomposição aeróbica da matéria seca por fungos e leveduras. Segundo Castro et al. (2001), que trabalharam com silagem de Tifton 85 sob efeito de pré emurchecimento prévio e de inoculante bacteriano-enzimático, o incremento na matéria seca restringiu o crescimento bacteriano devido à redução de água livre disponível no alimento.

Ferrari Júnior e Lavezzo (2001), em trabalho com capim-elefante emurchecido ao sol por 8 horas e ensilado, concluíram que o emurchecimento pela exposição do capim-elefante ao sol aumentou o teor de matéria seca da forragem $(27,7 \%)$, favorecendo o processo de ensilagem.

Segundo Morais (1999), a adição de produtos externos ao processo de ensilagem surgiu como forma de melhorar o resultado final da fermentação, alterando a matéria seca, carboidratos solúveis e/ou diminuindo o $\mathrm{pH}$ do material ensilado. A meta é encontrar um produto economicamente viável, que assegure a preservação eficiente desde o momento da abertura do silo até sua completa utilização.

Um aditivo ideal a ser utilizado na ensilagem de gramíneas tropicais deveria possuir, portanto alto teor de matéria seca, alta capacidade de absorver água, alto valor nutritivo, boa palatabilidade, elevado teor de carboidratos solúveis, fácil manipulação, boa disponibilidade de mercado e baixo custo de aquisição. Segundo revisão de Peres (1997), nenhum dos produtos dispostos e exaustivamente estudados nos últimos anos no Brasil se enquadra perfeitamente nestas condições.

O fubá de milho foi o produto mais tradicionalmente testado na ensilagem de gramíneas tropicais. Os resultados são positivos quando o fubá é aplicado em grande quantidade a ponto de interferir no teor de matéria seca do produto final e elevar o valor energético do material ensilado. Porém um dos possíveis impedimentos do emprego desta técnica deve-se ao elevado preço pago pelo milho (MORAIS, 1999).

Van Onselen; Lopez (1988) detectaram aumento de 163\% no teor de carboidratos solúveis quando adicionaram $7 \mathrm{Kg}$ de fubá de milho por tonelada de capim elefante cortado aos 105 dias de crescimento vegetativo. Elias et al. (1990) determinaram na sacharina teor de 
carboidratos solúveis ao redor de $40 \%$ na matéria seca. Esse resultado sugere que a adição desse produto à forragem de capim elefante deve aumentar o teor de carboidratos solúveis.

Ainda segundo o autor acima citado, compostos nitrogenados, tais como cama de frango e uréia podem auxiliar na estabilidade aeróbica do silo, quando da sua abertura; no entanto, podem também dificultar a queda do $\mathrm{pH}$ da massa ensilada, favorecendo a proliferação de microrganismos indesejáveis.

Quanto à adição de níveis crescentes de rolão de milho, farelo de trigo, espera-se que ocorram reduções na digestibilidade da fração fibrosa, conforme dados de Robertson; Van Soest (1972) citados por Faria (1982) e Boin (1975).

Andrade e Lavezzo (1998a,b), em experimento com silagem de capim-elefante confeccionada com adição de $0,8,16$ ou $24 \%$ de matéria seca de rolão de milho, farelo de trigo ou sacharina na forragem verde do capim, encontraram aumento na ingestão de matéria seca à medida que foi elevado o nível de aditivo na ensilagem.

\section{MATERIAL E MÉTODOS}

O experimento foi conduzido na Área Experimental da FAFRAM, localizada no Sítio das Acácias no município de Ituverava, estado de São Paulo, situado a 2047’30’ de latitude S e 474'30' de longitude W e na altitude de 631 metros, no período de 06/03/2007 à $10 / 05 / 2007$.

Foram confeccionadas silagens de capim-elefante (Pennisetum purpureum, cultivar Napier) de uma capineira já instalada, sendo que após 90 dias de descanso, o capim foi cortado manual, a planta foi picada em picadora movida pela TDP do trator específica para corte de forragens, em fragmentos de tamanho médio de $1,5 \mathrm{~cm}$.

Após a picagem e homogeneização da planta forrageira, cada alíquota foi tratada com o aditivo testado (Tabela 1) e armazenado em tubos de PVC (100 mm) (Figura 1) que foram enterrados $30 \mathrm{~cm}$ da base do tubo no solo e vedados com lona preta, e após 50 dias, foram retiradas amostras para análise bromatológica para posteriores determinações dos teores de proteína bruta, matéria seca e nitrogênio. Para essa análise foram descartados $15 \mathrm{~cm}$ da amostra na parte superior do tubo. 


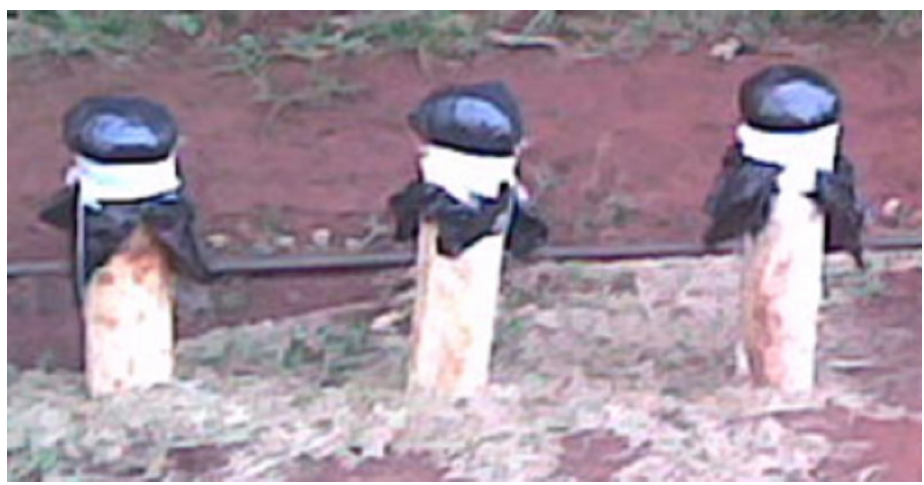

Figura 1- Tubos de PVC usados para armazenar o material ensilado.

Tabela 1: Tratamentos e Aditivos usados no trabalho, com suas quantidades:

\begin{tabular}{|c||l|c|}
\hline Tratamento & \multicolumn{1}{|c|}{ Aditivo } & Quantidade \\
\hline Trat. 1 & Silagem + Uréia & $0,5 \%$ \\
\hline Trat. 2 & Silagem + MDPS & $10 \%$ \\
\hline Trat. 3 & Silagem + Farelo de Soja & $10 \%$ \\
\hline Trat. 4 & Silagem + Fubá de Milho & $10 \%$ \\
\hline Trat. 5 & Silagem + Farelo de Trigo & $10 \%$ \\
\hline Trat. 6 & Testemunha & ----- \\
\hline
\end{tabular}

${ }^{1}$ Milho Desintegrado com Palha e Sabugo

O delineamento utilizado foi o inteiramente casualizado (DIC), com 6 tratamentos e três repetições de cada tratamento, onde avaliou-se o teor de matéria seca, proteína bruta e teor de nitrogênio, no laboratório da Faculdade Dr. Francisco Maeda - FAFRAM.

Os resultados dos teores de matéria seca, proteína bruta e teor de nitrogênio foram submetidos a analise de variância através do programa ESTAT e as médias comparadas entre si pelo teste de Tukey (5\% de erro).

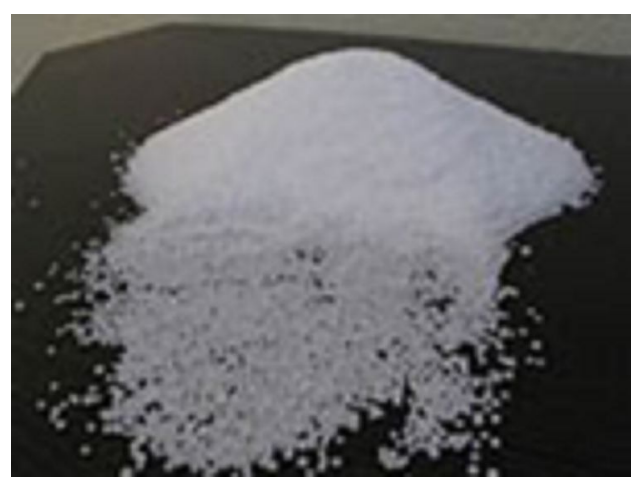

Figura 2 - Trat. 1: Uréia 


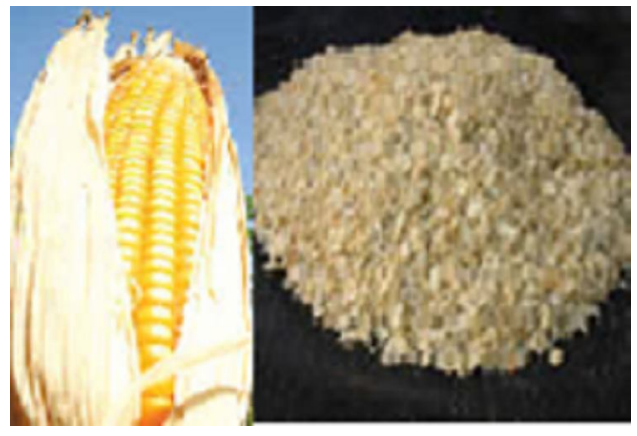

Figura 3 - Trat. 2: MDPS

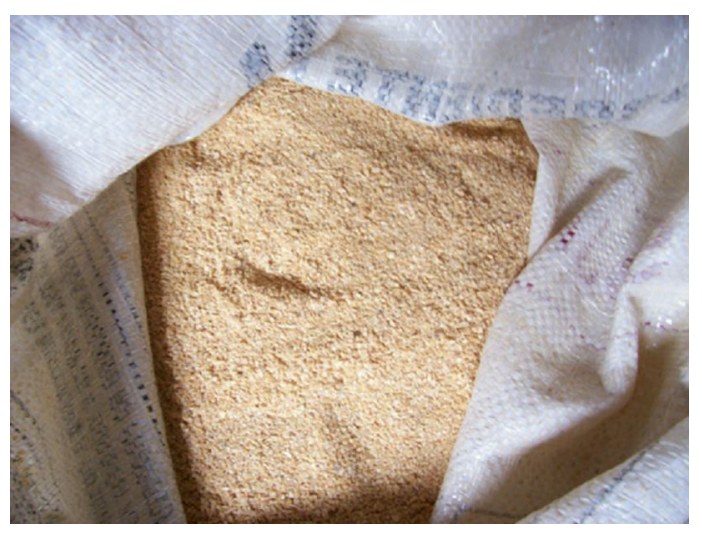

Figura 4 - Trat. 3: Farelo de Soja

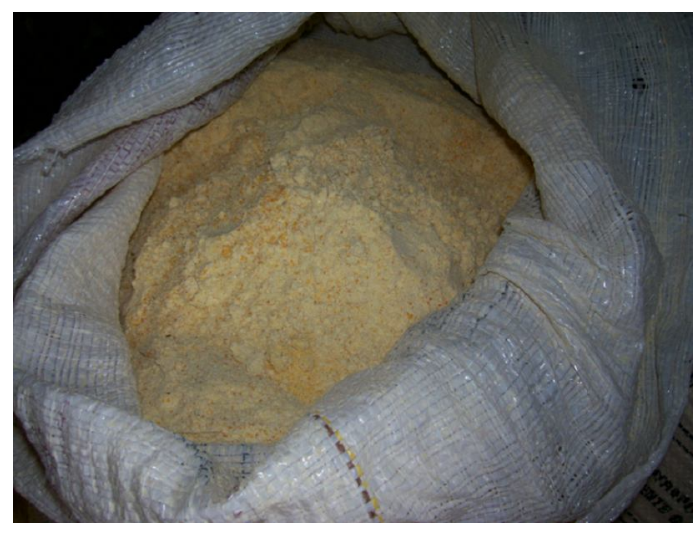

Figura 5 - Trat.4: Fubá de Milho 


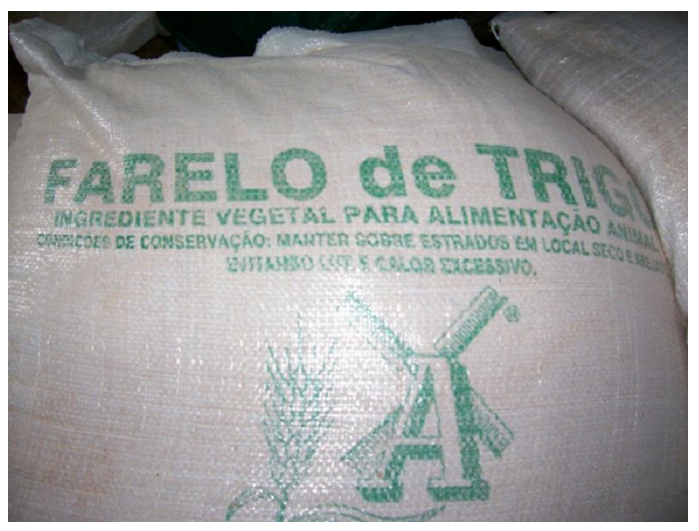

Figura 6 - Trat. 5: Farelo de Trigo

\section{RESULTADOS E DISCUSSÃO}

$\mathrm{Na}$ Tabela 2, são mostrados os valores médios das porcentagens de matéria seca $(\% \mathrm{MS})$, proteína bruta $(\% \mathrm{~PB})$ e de nitrogênio $(\% \mathrm{~N})$, na ensilagem de capim elefante utilizando diferentes aditivos. Verificou-se que para porcentagem de matéria seca não apresentou diferenças significativas, evidenciando que o uso do aditivo não interferiu nos resultados. Para os teores de proteína bruta $(\% \mathrm{~PB})$ e de nitrogênio $(\% \mathrm{~N})$, o uso do aditivo melhorou a qualidade da silagem, sendo que quando o farelo de soja foi adicionado ao capim elefante, apresentou melhor resultado, com médias de $15,47 \%$ e $2,47 \%$, respectivamente.

Tabela 2. Valores médios das porcentagens de matéria seca (\%MS), proteína bruta (\%PB) e de nitrogênio $(\% \mathrm{~N})$, na ensilagem de capim elefante utilizando diferentes aditivos.

\begin{tabular}{lccc}
\hline Tratamentos & $\mathbf{\%} \mathbf{M S}$ & $\mathbf{\% P B}$ & $\mathbf{\%} \mathbf{N}$ \\
\hline 1.Napier+Uréia & $30,40^{\mathrm{A}}$ & $3,94^{\mathrm{C}}$ & $0,63^{\mathrm{C}}$ \\
2.Napier+MDPS & $32,78^{\mathrm{A}}$ & $4,96^{\mathrm{C}}$ & $0,79^{\mathrm{C}}$ \\
3.Napier+F.Soja & $30,26^{\mathrm{A}}$ & $15,47^{\mathrm{A}}$ & $2,47^{\mathrm{A}}$ \\
4.Napier+F.Milho & $31,38^{\mathrm{A}}$ & $5,45^{\mathrm{BC}}$ & $0,87^{\mathrm{BC}}$ \\
5.Napier+F.Trigo & $29,60^{\mathrm{A}}$ & $8,43^{\mathrm{B}}$ & $1,35^{\mathrm{B}}$ \\
6.Testemunha & $27,08^{\mathrm{A}}$ & $4,32^{\mathrm{C}}$ & $0,69^{\mathrm{C}}$ \\
\hline Média Geral (\%) & 30,25 & 7,10 & 1,13 \\
\hline C.V. $(\%)$ & 13,21 & 17,68 & 17,74 \\
\hline
\end{tabular}

Médias seguidas da mesma letra, na coluna, não diferem estatisticamente pelo teste de Tukey ( $\mathrm{P}>0,05)$.

A adição de milho desintegrado com palha e sabugo (MDPS) na ensilagem de capim elefante apresentou percentagem de matéria seca de 32,78\%, com nível muito baixo de 
proteína bruta (4,96\%), contrariando observações feitas por McDonald; Whittenbury (1973) e por Van Soes (1994), que afirmam que fubás são utilizados para melhorar as condições de fermentação ou melhorar o valor nutritivo da silagem.

Segundo experimento de Rodrigues (2005), a adição de fubá de milho como aditivo no capim elefante, propiciou percentagens de Matéria Seca de $44,91 \%$ e Proteína Bruta de $7,93 \%$, valores esses superiores aos encontrados nesse trabalho, ou seja, percentagens de Matéria Seca e Proteína Bruta de 31,38\% e 5,45\%, respectivamente.

Andrade et al. (2004), avaliando silagem de capim-elefante com a adição de uréia, evidencia que o resultado foi satisfatório, verificando que a percentagem de Matéria Seca e Proteína Bruta foram de $16,10 \%$ e $9,17 \%$, os valores, diferentes dos encontrados nesse trabalho $(30,40 \%$ de matéria seca e $3,94 \%$ de proteína bruta)

O farelo de trigo usado na ensilagem do capim elefante teve percentagem de 29,60\% de MS e 8,43\% de PB, sendo que Andrade et al. (1998) encontraram 20,00\% e 10,44\% respectivamente.

\section{CONCLUSÃO}

Os diferentes tipos de aditivos utilizados na ensilagem de capim elefante, cv napier, influenciaram somente nas percentagens de proteína bruta e de nitrogênio, sendo que o farelo de soja, foi o que apresentou melhor resposta.

\section{REFERÊNCIAS}

ANDRADE, J. B; LAVEZZO, W. Aditivos na ensilagem do capim-elefante. III Valor nutritivo e consumo voluntário e digestibilidade em ovinos. Pesq. Agropec. Bras., v. 33, n. 12, p. 2015-2023, 1998a.

ANDRADE, J. B; LAVEZZO, W. Aditivos na ensilagem de capim-elefante. IV Fermentação ruminal em ovinos. Pesq. Agropec. Bras., v. 33, n. 12, p. 2025-2036, 1998 b.

ANDRADE, J. B. Produção de feno. Nova Odessa: Instituto de Zootecnia, 1999, 34 p. (Boletim técnico, n.44).

ANDRADE, S. J. T; MELOTTI, L. Efeito de alguns tratamentos sobre a qualidade da silagem de capim-elefante cultivar Napier (Pennisetum purpureum, Schum). Braz. J. Vet. Res. Anim. Sci., São Paulo, v. 41, n. 6, 2004. 
BOIN, C. Elephant (Napier) grass silage production: effect of addition on chemical composition, nutritive value and animal performance. Ithaca: Cornell Univ., 1975. 215p. Thesis (Ph D.).

CASTRO, F. G. F. et al. Perfil bacteriológico da silagem de Tifton 85 (Cynodon sp.) sob efeito de pré-emurchecimento e de inoculante bacteriano-enzimático. In: REUNIÃO ANUAL DA SOCIEDADE BRASILEIRA DE ZOOTECNIA, 38., 2001, Piracicaba. Anais... Piracicaba: SBZ, 2001. Trabalho 0578. CD ROM.

CORRÊA, L. A; POTT, E. B. Silagem de capim. In: SIMPÓSIO DE FORRAGICULTURA E PASTAGENS, 2., 2001, Lavras. Anais... Lavras: Universidade Federal de Lavras, 2001. p.255-271.

CORSI, M; MARTHA JR, G. B. Manutenção da fertilidade do solo em sistemas intensivos de pastejo rotacionado. In: SIMPÓSIO SOBRE MANEJO DE PASTAGENS, 14, Piracicaba, 1997. Anais... Piracicaba: FEALQ, 1997. p.327.

COWAN, R.T; LOWE, K .F. Tropical and subtropical grass management effects on coolseason grass forage quality. Grass for dairy cattle. CAB International. Ed. Cherney, J.H.; Cherney, D.J.R., 1998. 403p.

DEMARCHI, J. J. A. A; BOIN, C; BRAUN, G. A cultura do sorgo (Sorghum bicolor L. Moench) para a produção de silagens de alta qualidade. Zootecnia, v. 33, n.3, p. 111-136, 1995.

ELIAS, A.et al. Reseña descriptiva sobre el desarrollo de una tecnologia de enriquecimiento proteico em la caña de azúcar mediante fermentación en estado sólido (Sacharina). Revista Cubana de Ciencia Agrícola, Habana, v.24, n.1, p.1-12, 1990.

EVANGELISTA, A. R; ROCHA, G. P. Forragicultura. Lavras: Universidade Federal de Lavras/ Fundação de Apoio ao Ensino, Pesquisa e Extensão, 1997. 246 p.

FARIA, V. P. Efeito de níveis de energia e de proteína sobre a fermentação no rúmen, a digestibilidade de princípios nutritivos e o desaparecimento de matéria seca de forragem na fermentação "in vitro" e em sacos suspensos no rúmen. 1982. 137p. Tese (Livre Docência). Universidade de São Paulo. Escola Superior de Agricultura "Luiz de Queiroz". Piracicaba.

FERRARI JR, E; LAVEZZO, W. Qualidade da silagem de capim-elefante (Pennisetum purpureum Schum.) emurchecido ou acrescido de farelo de mandioca. Rev. Soc. Bras. Zoot., v. 30, n. 5, p. 1424-1431, 2001.

FERREIRA, J. J; SILVA, J. F. C; GOMIDE, J. A. Efeito do estádio de desenvolvimento, do emurchecimento e da adição de raspa de mandioca sobre o valor nutritivo da silagem do capim-elefante (Pennisetum purpureum Schum.). Experimentiae, v. 17, n. 1, p. 84-108, 1974.

HENDERSON, N. Aditivos de silagem. Ciência de Alimento animal e tecnologia, v.45, n.1, p.35-56, 1993. 
KISSMANN, K. G. Plantas infestantes e nocivas. 2. ed. São Paulo: BASF, 1997. Tomo I.

LAVEZZO, W. Ensilagem de capim-elefante. In: SIMPÓSIO SOBRE MANEJO DE PASTAGEM. Anais... 12., 1994, Piracicaba: FEALQ, 1994. p. 169-275.

McDOnALD, P; HENDERSON, A. R; HERON, S. J. E. The biochemisty of silage. Edinburg, J. Wiley and Sons Ltda, 1991. 226p.

McDONALD, P; HENDERSON, A. R; HERON, S. J. E. The biochemistry of silage. Marlow, UK: Chalcombe Publications, 1991.

McDONALD, P; WHITTENBURY, R. The silage process. In: BUTTLER, G.W. (Ed.). Chemistry and biochemistry of herbage. London: Academic, 1973. v.3, p.33-60.

MERRY, R. J; MACKENNA, C; JONES, RAYMOND. Biological silage addtives. Ciência e Investigacion Agraria, Santiago, v. 20, n2, p. 372-401, ago. 1993.

MORAIS, J. P. G. Silagem de gramíneas tropicais. In: SIMPÓSIO SOBRE NUTRIÇÃO DE BOVINOS, 7., 1999, Piracicaba. Anais... Piracicaba: FEALQ, 1999. p. 89-95.

NRC. NATIONAL RESEARCH COUNCIL. Nutrient Requeriments of Beef Cattle. 7. ed. Washington: National Academy Science, 1996. 242p.

ONSELEN, V. J. V; LOPEZ, J. Efeito da adição de fontes de carboidratos e de um produto enzimático comercial na composição químico-bromatológica da silagem de capim-elefante (Pennisetum purpureum, Schum.). Rev. Bras. Zoot., v. 17, n. 5, p. 421- 27, 1988.

PEDREIRA, J. V. S; MATTOS, H. B. Crescimento estacional de cultivares de capim elefante., n. 1, p. 29-41, 1982. (Boletim Indústria Animal. v. 39)

PEIXOTO, Aristeu Mendes Peixoto, et. al. Alimentação suplementar. SIMPÓSIO SOBRE NUTRIÇÃO DE BOVINOS,7, Anais... Piracicaba, 1999. Piracicaba: FEALQ, 1999. 195p.

PERES, J. R. Avaliação da polpa de citrus seca e peletizada como aditivo na ensilagem do capim elefante (Pennisetum purpureum, Schum). 1997. 82p. Dissertação (Mestrado). Universidade de São Paulo. Escola Superior de Agricultura Luiz de Queiroz.Piracicaba.

PUPO, Nelson Ignácio Hadler. Manual de pastagens e forrageiras: formação, conservação, utilização. Campinas: Instituto Campineiro de Ensino Agrícola, 1979. 343p.

REEVES, M. et al. A comparison of three techniques to determine the herbage intake of dairy cows grazing Kikuyu (Pennisetum clandestinum) pasture. Australian J. Exp. Agric. v.36, p.23-30, 1996.

REZENDE, A. V. et al. Efeito da mistura da planta de girassol (Helianthus annuus L.) durante a ensilagem do capim-elefante (Pennisetum purpureum Schum.) no valor nutritivo da silagem. Rev. Bras. Zoot., v. 31, n. 5, p. 1938-1943, 2002. 
ROCHA, F. C. et al. Níveis de uréia e períodos de amonização sobre o valor nutritivo da silagem de capim-elefante (Pennisetum purpureum Schum.) - cv. Napier. In: REUNIÃO ANUAL DA SOCIEDADE BRASILEIRA DE ZOOTECNIA, 38., 2001, Piracicaba. Anais... Piracicaba: SBZ, 2001. Trabalho 1179. CD ROM.

RODRIGUES, J. L. M. Avaliação da qualidade da silagem de capim elefante (Pennisetum purpureum Schmach), utilizando diferentes tipos de aditivos. Ituverava: FE/FAFRAM, 2005. 22p. Trabalho de Conclusão de Curso (Graduação em Engenharia Agronômica) Faculdade Dr. Francisco Maeda. Fundação Educacional de Ituverava.

SANTOS, F. A. P. S; JUCHEM, S. O. Sistemas de produção de leite a base de forrageiras tropicais. In: SISTEMAS DE PRODUÇÃO DE LEITE, Passo Fundo, RS, 2001. Anais... Passo Fundo: Sist. Prod. Leite, 2000. p.250.

SOUZA, A L. et al. Valor nutritivo da silagem de capim-elefante Pennisetum purpureum Schum. cv. Cameroon com diferentes níveis de casca de café. In: REUNIÃO ANUAL DA SOCIEDADE BRASILEIRA DE ZOOTECNIA, 38., 2001, Piracicaba. Anais... Piracicaba: SBZ, 2001. Trabalho 0800. CD ROM.

TOTH, I; RYDIN, C; NILSSON, R. Studies on fermentation processes in silage: comparison of different types of forage crops. Archiv für Mikrobiologie, Heidelberg, v.25, n.2, p.208$218,1956$.

VAN SOEST, P. J. Nutritional ecology of the ruminant. 2.ed. Ithaca: Cornell University, 1994. 476p.

VILELA, D. Utilização do capim elefante na forma de forragem conservada. In: SIMPÓSIO SOBRE CAPIM ELEFANTE, 1990, Coronel Pacheco, MG. Anais... Juiz de Fora, MG: EMBRAPA-CNPGL, p. 89-131, 1990.

VILELA, D; CRUZ, G. M; CARVALHO, J. L. H. Efeito de alguns aditivos sobre a qualidade e valor nutritivo da silagem de capim-elefante. EMBRAPA -CNPGL, 1982. 15 p. (Circular Técnica, n.15)

WIERINGA, G. W. The effect of wilting on butyric acid fermentation in silage. Netherlands J. Agric. Sci., v.6, n.3, p.204 -210, 1958. 